\title{
Live Freeze-Dried Lactic Acid Bacteria Probiotic
}

National Cancer Institute

\section{Source}

National Cancer Institute. Live Freeze-Dried Lactic Acid Bacteria Probiotic. NCI

Thesaurus. Code C61505.

A probiotic containing live, cultivated, freeze-dried lactic acid bacteria with gastrointestinal (Gl) protective, anti-inflammatory, immunomodulating and potential antitumor properties. Oral administration of probiotic bacteria help maintain adequate colonization of the Gl tract and modulate the composition of the normal microflora. Upon colonization of the Gl tract, the probiotic bacteria form a protective barrier, interfere with the attachment of pathogenic bacteria and other harmful substances and may bind to and degrade carcinogens. This may prevent inflammation and possibly cancer. In addition, these bacteria produce lactic acid, thereby creating an acidic environment that is unfavorable for pathogens. 